\title{
Hearing and seeing \\ Unusual early signs of Wernicke encephalopathy
}
Figure Axial FLAIR imaging showed a symmetric hyperintense lesion of the inferior colliculi (A) with slight contrast (gadolinium) enhancement on T1-weighted images (B)
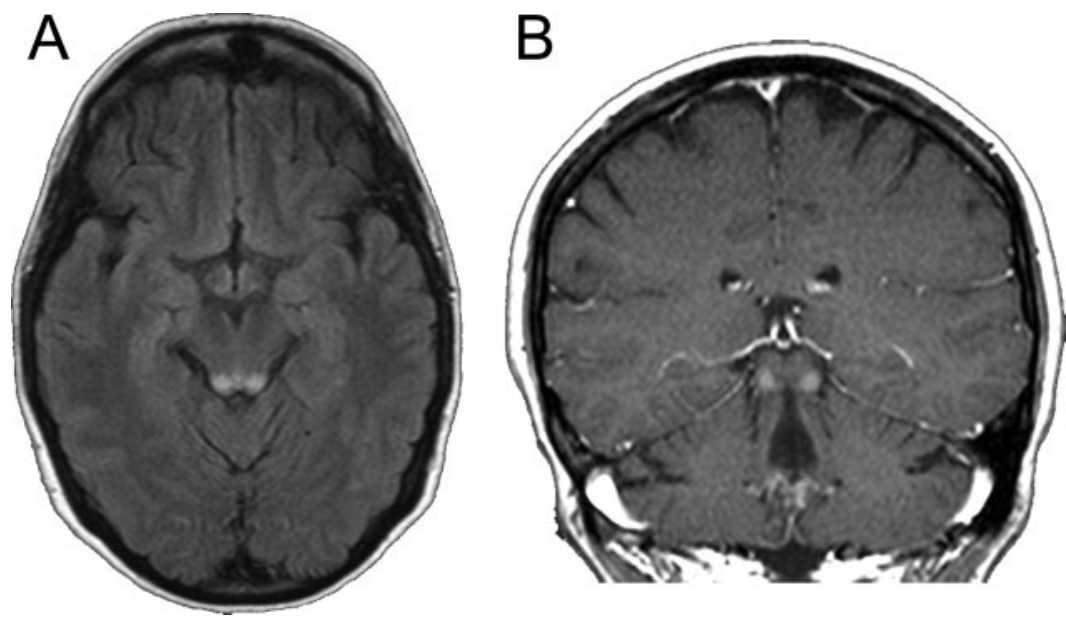

A 31-year-old woman with Crohn disease presented with tinnitus, headache, apathy, blurred vision, and nystagmus after 3 weeks of IV nutrition and partial colectomy. MRI showed abnormalities of the inferior colliculi (figure). Serum thiamine was low $(56 \mathrm{nM} / \mathrm{L}$, normal $>66)$ and symptoms resolved within 48 hours of thiamine IV supplementation, suggestive of Wernicke encephalopathy (WE). MRI usually shows damage of the mammillary bodies and paraventricular region. Hearing loss has been reported in WE, ${ }^{1}$ but not in relation with a lesion of the inferior colliculi, which is the first to occur in a nonhuman primate model of thiamine deficiency. ${ }^{2}$

O. Flabeau, MD, A. Foubert-Samier, MD, W. Meissner, MD, PhD, and F. Tison, MD, PhD, Bordeaux, France

Disclosure: The authors report no disclosures.

Address correspondence and reprint requests to Dr. F. Tison, Department of Neurology, Hôpital du Haut Lévêque, University Bordeaux 2, Avenue Magellan, 33604 Pessac cedex, France; francois.tison@chu-bordeaux.fr

1. Buscaglia J, Faris J. Unsteady, unfocused, and unable to hear. Am J Med 2005;118:1215-1217.

2. Witt ED, Goldman-Rakic PS. Intermittent thiamine deficiency in the rhesus monkey, I: progression of neurological signs and neuroanatomical lesions. Ann Neurol 1983;3:376-395. 


\section{Neurology}

\section{Hearing and seeing: Unusual early signs of Wernicke encephalopathy \\ O. Flabeau, A. Foubert-Samier, W. Meissner, et al. \\ Neurology 2008;71;694 \\ DOI 10.1212/01.wnl.0000324599.66359.b1}

This information is current as of August 25, 2008

\section{Updated Information \& Services}

\section{References}

Subspecialty Collections

Permissions \& Licensing

Reprints including high resolution figures, can be found at: http://n.neurology.org/content/71/9/694.full

This article cites 2 articles, 0 of which you can access for free at: http://n.neurology.org/content/71/9/694.full\#ref-list-1

This article, along with others on similar topics, appears in the following collection(s):

All Medical/Systemic disease

http://n.neurology.org/cgi/collection/all_medical_systemic_disease Audition

http://n.neurology.org/cgi/collection/audition

MRI

http://n.neurology.org/cgi/collection/mri

Tinnitus

http://n.neurology.org/cgi/collection/tinnitus

Information about reproducing this article in parts (figures,tables) or in its entirety can be found online at:

http://www.neurology.org/about/about_the_journal\#permissions

Information about ordering reprints can be found online:

http://n.neurology.org/subscribers/advertise

Neurology ${ }^{\circledR}$ is the official journal of the American Academy of Neurology. Published continuously since 1951, it is now a weekly with 48 issues per year. Copyright . All rights reserved. Print ISSN: 0028-3878. Online ISSN: 1526-632X.

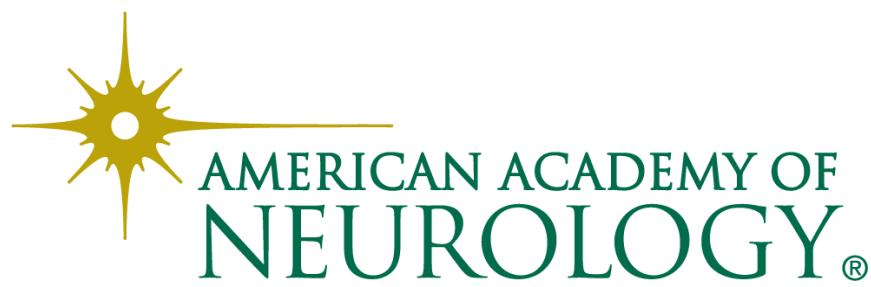

